\title{
The importance of environmental differences in the structuring of rotifer functional diversity
}

\author{
Anita GALIR BALKIĆ* \\ Department of Biology, Josip Juraj Strossmayer University of Osijek, Cara Hadrijana 8/A, 31000 Osijek, Croatia
}

\begin{abstract}
A dynamic change in environmental conditions among floodplain habitats with different geomorphology might be a significant trigger in determining rotifer functional diversity. The aim of the study was to test the importance of environmental differences between several waterbody types, their positions within the floodplain and supporting microcrustacean communities in the structuring of rotifer functional feeding guilds. The study was conducted in Kopački rit floodplain during 2008 at five sites (two lakes, two channels and the main river). ANOSIM showed a significant difference in spatial distribution among rotifer feeding guilds. Redundancy analyses indicated biotic variables to significantly influence rotifer functional diversity in lake systems while in channel environments and the main riverbed guild representation was mainly influenced by limnological variables. Individual guild abundance changed relative to the site position within the floodplain as well, where the increased distance from the main riverbed resulted in increased rotifer numbers, and a different proportion of microfilter-feeders and macrofilter-feeders was recorded. The multiple linear regression showed a significant relation of macrofilter-feeder rotifers with microcrustaceans pointing to notable exploitative competition among these groups. The results highlight the ecological importance of all types of natural floodplain habitats necessary for preserving and maintaining the rotifer diversity.
\end{abstract}

\section{INTRODUCTION}

In floodplain habitats, hydrological connectivity, flood duration, time and scale of flooding (Junk et al., 1989; Hein et al., 2003; Wantzen et al., 2008) influence the abundance, biomass, and diversity of plankton communities. Alongside the change in environmental parameters that come with the alteration in a hydro regime, the hydrology of the area affects plankton biotic interactions as well (Schöll et al., 2012; Galir Balkić et al., 2018b). In understanding the rotifer ecology in floodplain areas, special attention should be given to studying rotifer communities of different habitat types (Dembowska and Napiórkowski, 2015). Paidere (2012) showed that a flooding regime and its frequency can structure a rotifer community, especially considering the position of waterbodies within the floodplain area. These

Corresponding author: agalir@biologija.unios.hr

Keywords: Microfilter-feeders; macrofilter-feeders; competition; predation; floodplain; River Danube.

Edited by: Diego Fontaneto, CNR-IRSA Water Research Institute, Verbania, Italy.

Received: 18 March 2019

Accepted: 14 June 2019.

This work is licensed under a Creative Commons Attribution NonCommercial 4.0 License (CC BY-NC 4.0).

${ }^{\circ}$ Copyright: the Author(s), 2019

Licensee PAGEPress, Italy

J. Limnol., 2019; 78(3): 284-295

DOI: 10.4081/jlimnol.2019.1903 habitats often diverge in their geomorphology (Amoros and Bornette, 2002) that directly determines the effects of the flooding and influences the functional diversity of rotifers.

Rotifers represent a very diverse group of invertebrates. They are characterised by fast growth and reproduction potential, which is why they are classified as r-strategists in freshwater environments. As such, a group of rotifers tolerates a wide range of environmental conditions. However, they are considered a good indicator of the trophic state of the waterbody (Sládeček, 1983) as each species expresses a species-specific preference towards a particular environment. For example, conductivity, a highly variable parameter in floodplain areas, has an opposite effect on different species. While some rotifers tolerate increased conductivity values, others diminish in conditions of high conductivity (Galir Balkić et al., 2018b). The same pattern is observed in water temperature, $\mathrm{pH}$ or the trophic state of the water body (Bērziņš and Pejler, 1987, 1989a, 1989b; Duggan et al., 2002; Van der Gucht et al., 2007; Gutkowska et al., 2013). Meanwhile, it is not uncommon for different habitat types within the same floodplain to diverge into their limnological parameters (Weigelhofer $e t$ al., 2014; Galir Balkić et al., 2018a). This situation indicates that different habitat types within the same floodplain area may support diverse rotifer communities. Such is especially important in maintaining high biodiversity levels.

Rotifers are very important micro-grazers in freshwater ecosystems. They influence bacteria and phytoplankton communities with a high efficiency of carbon transfers to higher trophic levels (Kim et al., 2000). Rotifer control over the bacterioplankton is of vital importance in freshwater environments (Ooms-Wilms et al., 1995), especially when considering the high 
competition between bacteria and phytoplankton for necessary nutrients (Joint et al., 2002) and the subsequent effects of this interaction on phytoplankton growth. The low abundance of bacterioplankton grazers has a significant impact on the entire food-web structure (Rubin and Leff, 2007). Controlling the phytoplankton is essential in habitats with often cyanobacterial blooms. Certain rotifer species (like Brachionus sp.) can feed on these "inedible" phytoplankton (Soares et al., 2010) and often flourish in such conditions. On the other hand, phytoplankton species that occur together with cyanobacteria may not be high-quality food or may appear in low abundance and thus cause negative effects on other herbivorous rotifers (Gilbert, 1996). Besides the top-down impact of rotifers on lower trophic levels, they also interact with cladocerans and juvenile copepods through exploitative competition and are a valuable food source for higher trophic levels such as copepods and other invertebrates (Špoljar et al., 2017).

In floodplain ecosystems, where rotifers are a predominant group of zooplankton (Baranyi et al., 2002; Lansac-Tôha et al., 2009; Goździejewska et al., 2016) hydrology plays a crucial role for all zooplankton growth and reproduction (Reckendorfer et al., 1999; Baranyi et al., 2002; Zimmermann-Timm et al., 2007). Flooding causes the homogenization of floodplain waterbodies (Thomaz et al., 2007), and reduces zooplankton abundance through the wash-out events (Czerniawski et al., 2016). Excess input of suspended clay particles through hydrological oscillation interrupts the feeding of all zooplankton groups. However, rotifers are less affected by this interference than microcrustaceans (Kirk and Gilbert, 1990). Rotifers can also adapt and respond to short-term environmental variability (Bonecker et al., 2009; Śpoljar et al., 2012), including the variability of food resources, with their species abundance and diversity's being directly related to food availability (Hampton, 2005; Galir Balkić et al., 2018b; JiménezContreras et al., 2018).

A large proportion of the rotifer studies focus on identifying species composition and diversity, abundance, and at times, biomass (Sharma and Sharma, 2005; Schöll and Kiss, 2008; Bonecker et al., 2009; Okogwu, 2010). Recently, studies of the functional characteristics of zooplankton (Obertegger et al., 2011; Špoljar et al., 2011b; Benedetti et al., 2016; Lokko et al., 2017; Obertegger and Flaim, 2015, 2018) and other animal groups (Farias and Jaksic, 2006) have been used more frequently. The use of functional guilds, which are described as groups of species that utilize the same resources in a similar manner (Simberloff and Dayan, 1991), distinguish different communities well (Smith et $a l ., 2009$ ) and might be a useful tool in describing trophic relationships in waterbodies of the elevated trophy (Wen et al., 2017). Galir Balkić et al. (2018b) demonstrated that the use of the functional approach can detect differences in the feeding preferences of a studied community and that the use of functional feeding guilds can give the right image of planktonic food web conditions. By using a trophic group approach, food webs can be simplified without the loss of data content (Gauzens et al., 2015).

The aim of this study was to test the importance of environmental differences in the structuring of rotifer functional diversity between different habitats. I hypothesised that rotifer functional diversity would be affected by i) the type of waterbody, ii) the position of the waterbody within the floodplain, and iii) biotic interactions with microcrustaceans.

\section{METHODS}

\section{Field sites}

Kopački Rit Nature Park is a worldwide known floodplain area positioned in NE Croatia $\left(45^{\circ} 36^{\prime} \mathrm{N} ; 18^{\circ} 48^{\prime}\right.$ E; $80.5 \mathrm{~m}$ asl) in the Central European part of the Danube River (Fig. 1) covering a zone of about $177 \mathrm{~km}^{2}$. The floodplain terrain has higher grounds on the east towards the Danube and lowers towards the inland side of the floodplain. Due to different geomorphology and distances to the main river bed, five different habitat types were chosen as sampling sites (two lakes: Sakadaš and Kopačko; two channels: Čonakut and Hulovo; and the main river bed). Lake Sakadaš is the deepest water depression in the Kopački rit, situated $10 \mathrm{~km}$ away from the Danube. The lake has a total surface of ca. $0.12 \mathrm{~km}^{2}$ and a mean depth of 6-8 m. The lake is intertwined with the rest of the floodplain waterbodies via the Čnakut Channel. The channel has a mean depth of $2-5 \mathrm{~m}$ and is $30 \mathrm{~m}$ wide and $3 \mathrm{~km}$ long. The most common vegetation found in this area is an association of ScirpoPhragmitetum and Caricetum sp. The channel stretches to Lake Kopačko, which is the largest lake in the Kopački rit floodplain. Lake Kopačko has an average area of 2-2.5 $\mathrm{km}^{2}$ (Bonacci et al., 2002) and depth varying from 1 to $>5 \mathrm{~m}$ that is mainly determined by the fluctuating Danube water level. The area around the lake is enclosed by slopes and lush vegetation of Potamogetonetum lucentis and Potamogetonetum graminei (Mihaljević et al., 1999). The Hulovo Channel is a direct connection of the floodplain with the main riverbed and a connection to Lake Kopačko. The channel has a mean depth of 3.5-5 m and is up to $34 \mathrm{~m}$ wide and $6 \mathrm{~km}$ long. The channel is characterised by shore erosion with steep shore slopes and abundant forests of white willow (Galio-Salicetum albae) and forests of white willow and black poplar (SaliciPopuletum nigrae) on higher terrains (Mihaljević et al., 1999). The River Danube (Fig. 1) in this section has a 
mean water level of $2.63 \mathrm{~m}$ (Mihaljević et al., 2015) and an average width of $450 \mathrm{~m}$ (Bonacci et al., 2002). As a result of a reduced slope in this section, the river is meandering and has a velocity of about $0.4 \mathrm{~ms}^{-1}$ (Peršić and Horvatić, 2011). The River Danube has the strongest influence on oscillations in the water regime of the entire floodplain area and defines the degree of hydrological connectivity in Kopački rit (Tadić et al., 2002).

\section{Sampling and zooplankton identification}

At all studied sites, sampling was conducted in the middle of the water bodies, mainly representing their deepest parts. Samples were taken monthly from January until December 2008.

During each sampling, event samples were taken approximately $20 \mathrm{~cm}$ under the water surface. For a rotifer and microcrustacean analysis, a Van Dorn sampler was used to collect $10 \mathrm{~L}$ of lake water that was subsequently filtered through a $25 \mu \mathrm{m}$ mesh net and in situ preserved in a $4 \%$ formaldehyde solution. For rotifer determination, a minimum of 500 individuals was counted in each sample. For a microcrustacean analysis, the entire sample was counted. All zooplankton was identified to species level according to the specialised literature (see in Galir Balkić et al., 2018a).

A portable multimeter multi 340iSET (WTW) was used to measure in situ water temperature (WT), dissolved oxygen (DO), and conductivity. Transparency (SD) was estimated using the Secchi disc and water depth (WD) was measured with a labelled weighted rope. In the laboratory, several analyses were performed to collect data on concentrations of ammonium $\left(\mathrm{NH}_{4}\right)$, nitrites
$\left(\mathrm{NO}_{2}\right)$, nitrates $\left(\mathrm{NO}_{3}\right)$, organic nitrogen (org $\left.\mathrm{N}\right)$, total nitrogen (TN) and total phosphorus (TP). These analyses were conducted according to APHA (1992). For the determination of Chlorophyll- $a$ concentrations (Chl- $a$ ), $1 \mathrm{~L}$ of water was filtered through Whatman $\mathrm{GF} / \mathrm{C}$ glassfibre membranes and later extracted with acetone while Chl- $a$ concentrations were computed according to UNESCO (1966) and Strickland and Parsons (1968). Measurements of the water flow were conducted daily at the Apatin gauge ( $\mathrm{r} \mathrm{km} \mathrm{1401,} \mathrm{Republic} \mathrm{of} \mathrm{Serbia),} \mathrm{and}$ were supplied by the legal entity for water management of Croatian waters.

\section{Data analyses}

All rotifer species were aggregated into functional feeding guilds (microfilter-feeders, A1, A2, A3; macrofilter-feeders, B3, B5, B6, B7; and predators, C) according to Karabin (1985), as this classification gives a reflection of different food preferences. Microfilterfeeders represent detritivorous (sedimentators), and macrofilter-feeders imply algivorous (raptorial) species (for more detail see Galir Balkić et al., 2018b).

All microcrustacean individuals were divided into groups as follows: 1) Daphnia - large herbivores; 2) small Cladocera - feeding on smaller food particles than Daphnia; 3) juvenile copepoda (nauplii and copepodite stages) - herbivores feeding on smaller food particles than Daphnia; 4) adult Copepoda - omnivores. The size category for cladocerans was used as the mesh of the feeding limbs determine the size of collected food (Brendelberger, 1991), and there is strong exploitative competition between different cladoceran size classes

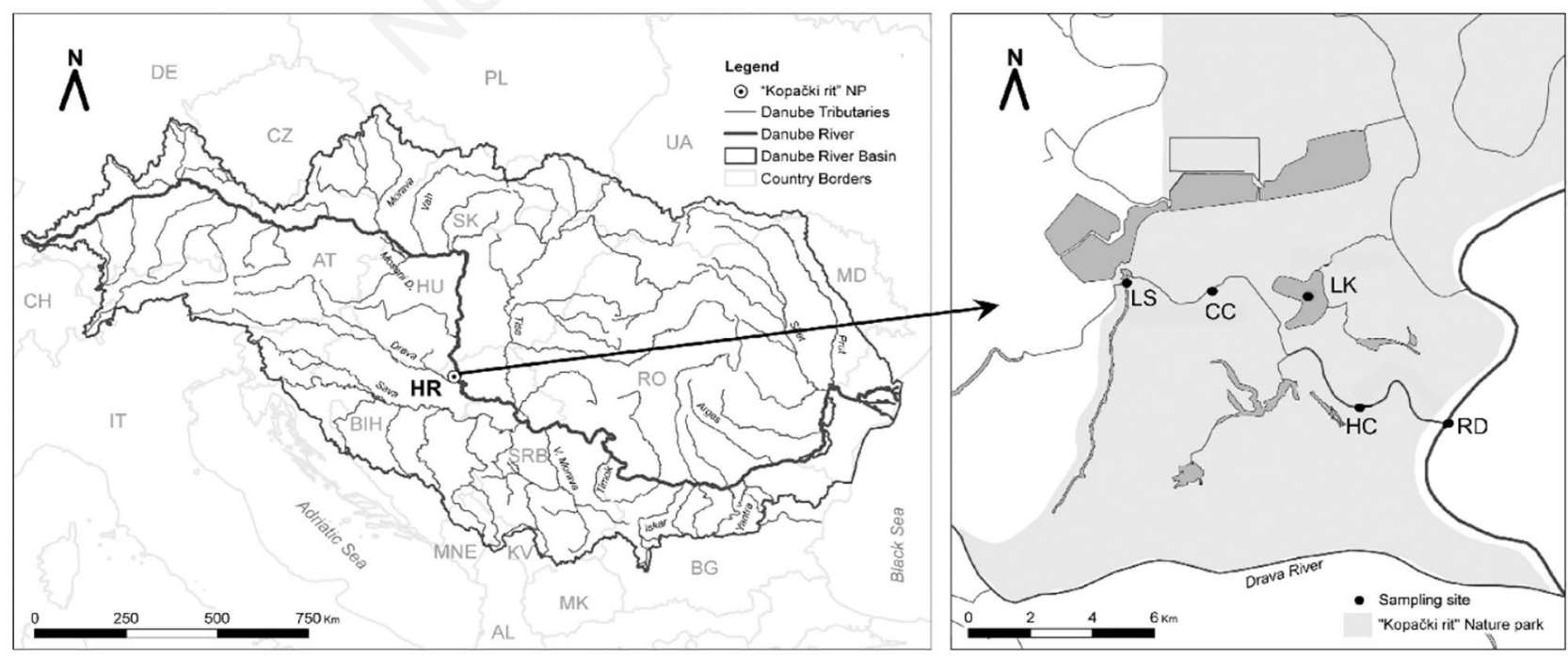

Fig. 1. Map of the study area. Black circles mark sampling points. 
(large/small) (Romanovsky and Feniova, 1985). The aforementioned groups of microcrustaceans are used in statistical analyses to test the significance of biotic interactions with rotifers. As chlorophyll $a$ is an indicator of algal biomass, it was used as a proxy for rotifer food availability.

Non-metric multidimensional scaling (nMDS) and cluster analyses were used to analyse the distribution of rotifer functional feeding guilds. Cluster analyses was based on a similarity matrix that grouped samples starting with the highest mutual similarities (Clarke and Warwick, 2001), and the result was a formation of a dendrogram where the $x$-axis represents the full set of samples and the $y$-axis shows a similarity level (Clarke and Warwick, 2001). The cluster analysis is presented as an nMDS overlay. An analysis of similarity (ANOSIM) was used to test for differences in rotifer functional guild abundances among different study sites, and a SIMPER analysis was performed in order to identify specific feeding guilds that primarily contribute to these differences. Square-root transformed abundance data were used in all analyses and based on the Bray-Curtis similarity measure. For these statistical analyses, the PRIMER v. 5.0 software package (Clarke and Warwick, 2001) was used.

Multiple linear regression analysis was used to determine the effects of measured biotic (explanatory) variables on rotifer functional feeding guilds (response variable). This statistical analysis was conducted using software Statistica 12.0 (StatSoft, Inc.).

Redundancy analyses (RDA) was used to test the relationships between limnological data and rotifer functional feeding groups at an individual study site. The analysis was performed by CANOCO for Windows version 4.5 software package (ter Braak and Šmilauer, 2002). Rotifer functional feeding guilds abundance data was prior to analyses, log-transformed, and centered by species. The significance of explanatory variables was tested by Monte Carlo permutation under the model with 499 permutations, and only variables significantly contributing to the rotifer functional diversity were left.

In statistical analyses, the differences were considered significant at $\mathrm{P}<0.05$.

\section{RESULTS}

\section{Environmental data}

Water levels normally oscillated throughout the year without any extreme hydrological events (Fig. 2). In Lake Sakadaš, water depth oscillated with an amplitude of $3.83 \pm 1.08 \mathrm{~m}$ between minimal and maximal water depth, while in Čonakut channel, Lake Kopačko, and Hulovo channel these amplitudes were less pronounced, ranging $2.84 \pm 0.85,2.07 \pm 0.71$ and $2.71 \pm 0.98 \mathrm{~m}$, respectively. The biggest change in water depth was recorded in the River Danube with an amplitude of $4.91 \pm 1.66 \mathrm{~m}$.

Higher transparency was recorded in lakes compared to the studied channels (Fig. 3) with a trend of increased transparency values in the marginal sites. Conductivity decreased towards the main river bed (Fig. 3), and sites farthest from the main river recorded the highest mean conductivity. Nitrate concentration indicated a decreasing trend towards the inland of a floodplain (Fig. 3) as was noticed for total nitrogen concentrations as well.

\section{Interaction of abiotic and biotic variables}

Rotifer functional feeding guilds in lake environments were highly influenced by biotic components (Fig. 4). The impact of biotic variables was especially pronounced in Lake Kopačko, where small cladocerans, juvenile, and adult copepods explained the majority of the total variance. On the contrary, in channels and the main river bed limnological variables mainly determined rotifer representation. For site close to the main river bed, Hulovo Channel, abiotic components explained $92.5 \%$ of the total rotifer feeding guild variance (Fig. 4).

\section{Functional feeding guild distribution and interrelationship}

Rotifer functional group abundance also differed among sites (Tab. 1). The greater rotifer abundance was recorded, the more remote the site was from the main riverbed (Tab. 1). The proportion of measured rotifer functional feeding guilds also differed among sites. In Lake Sakadaš, the ratio of microfilter-feeders to macrofilter-feeders was 1:2, while in Lake Kopačko, the ratio was 1:1. In channel environments, the same ratio was 1:3 in the Conakut Channel and 1:2 in the Hulovo Channel (Tab. 1). This ratio continued to decrease towards the River Danube and was almost 1:1 there, as in Lake Kopačko. Among similar habitat types, e.g., lakes (Lake

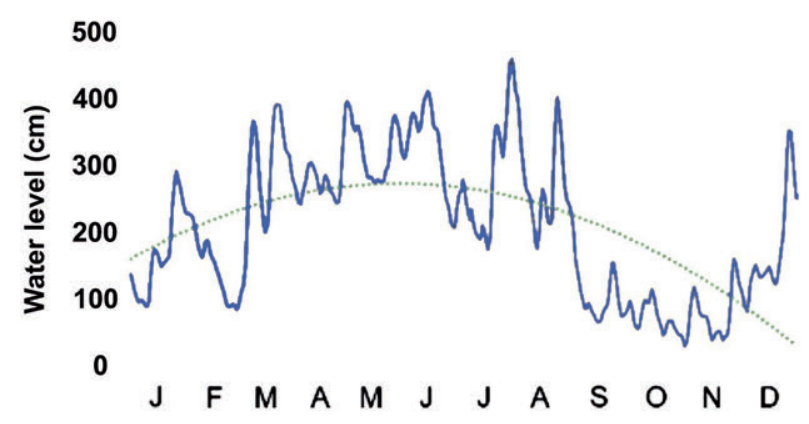

Fig. 2. Daily (January $1^{\text {st }}$ - December $31^{\text {st }}$ ) water level fluctuations at the Apatin gauging station in 2008. 
Sakadaš and Lake Kopačko) and channels (Čonakut Channel and Hulovo Channel), only the abundance of predators was alike throughout the study (Tab. 1).

An nMDS indicated a clear separation of rotifer communities in the studied sites based on the feeding guild approach where two major and five minor groups were distinguished (Fig. 5). Two major groups were recognised in the cluster dendrogram: one represented lake ecosystems (Lake Sakadaš and Lake Kopačko) and the second major group represented habitats with
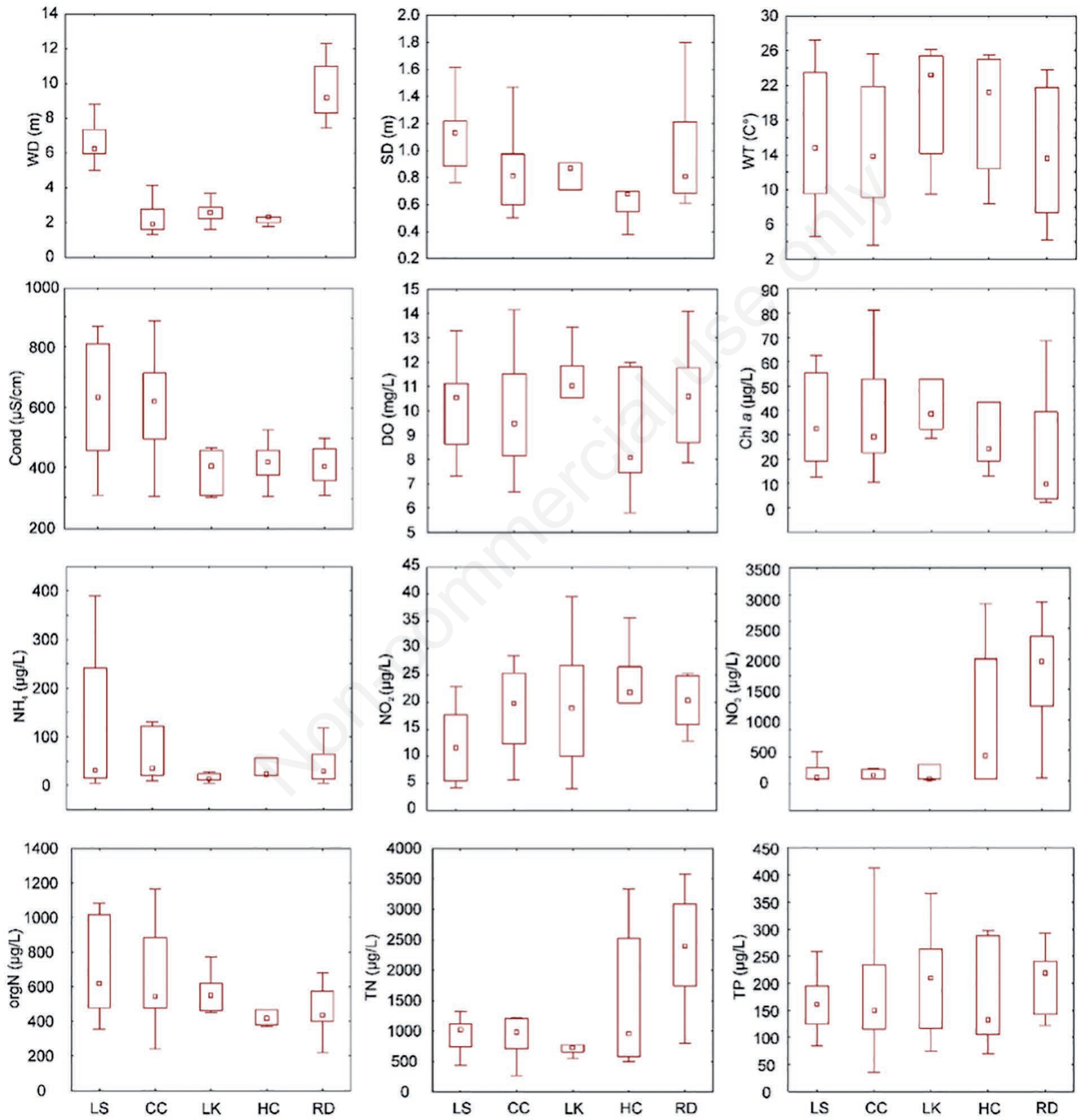

25\%-75\% प Median I Non-Outlier Range

Fig. 3. Box plot of measured environmental parameters at the studied sites. The square represents the median, and the boxplot margins indicate the first and third quartiles. 

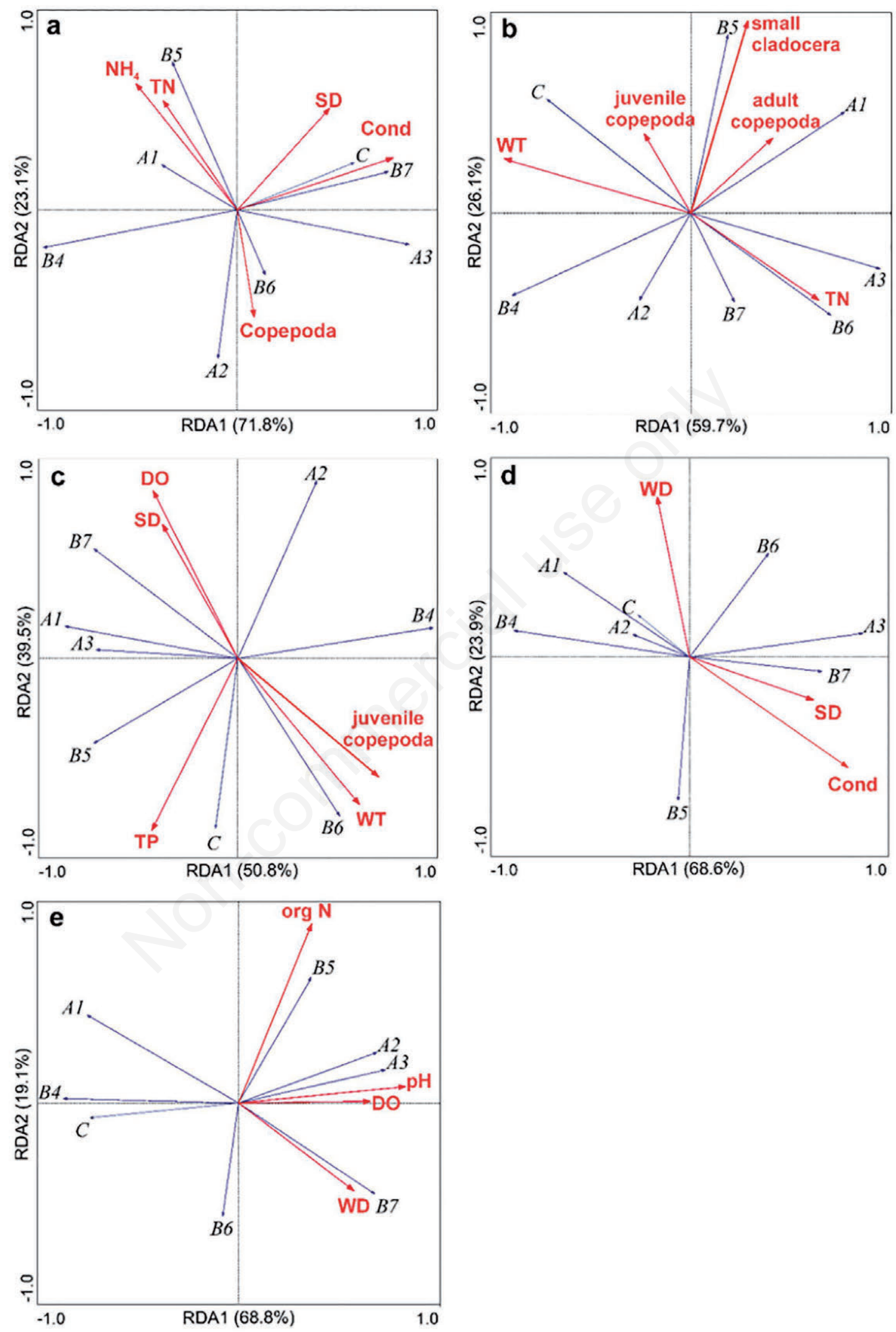

Fig. 4. RDA ordination plots showing the contribution of measured limnological and biotic parameters on rotifer functional feeding guilds at an individual study site: a) Lake Sakadaš, b) Lake Kopačko, c) Čonakut channel, d) Hulovo channel, e) River Danube. 
increased water flow (Hulovo Channel and the River Danube) (Fig. 5). Even though Čonakut represents a channel environment, it was under great influence from lake ecosystems, with which it shared a $40 \%$ similarity in rotifer assemblage. The one-way ANOSIM global test indicated a difference in rotifer functional feeding guilds among the studied sites (R-value: 0.41, P-value: 0.001) where A1 and B6 groups largely contributed to this discrimination (Tab. 2).

\section{Biological relations}

Among microfilter-feeders, microcrustacean abundance affected only the $\mathrm{A} 3$ group and explained 16\% of the rotifer variance (Tab. 3), and adult copepods significantly contributed to this result. Macrofilterfeeders, especially B4 and B5 groups, were strongly affected by the presence of juvenile copepods. However, the highest impact of total microcrustacean abundance was noticed in B6, where microcrustaceans explained $40 \%$ of the rotifer functional variance. B7 was the only macrofilter-feeder group that showed no dependence with microcrustaceans, and their abundance explained only $1 \%$ of the B7 group variance (Tab. 3).

\section{DISCUSSION}

Studying the importance of environmental parameters in the structuring of rotifer functional diversity revealed that even among similar habitat types, different rotifer communities exist. In Lake Sakadaš, larger macrofilterfeeders were affected by the abundance of adult copepods while small microfilter-feeders were dependent on limnological parameters. Yet, in the Lake Kopačko, the entire rotifer community was mainly under the influence of biotic interactions with microcrustaceans, suggesting a complex set of interactions in the planktonic food web at this site. The difference in rotifer representation between these lakes may be a consequence of their geomorphology with a greater mean depth of Lake Sakadaš compared to Lake Kopačko supporting the development of different plankton assemblages in bottom water layers (Palijan and Galir Balkić, 2018). Also, there is a marked difference in vegetation among these lakes that serve as microhabitats for zooplankton development.

In channel environments, macrofilter-feeders, especially B6, were affected by the abundance of juvenile copepods in Čonakut channel, while no such relationship was established in the Hulovo channel. The importance of biotic component in the Čonakut channel might be

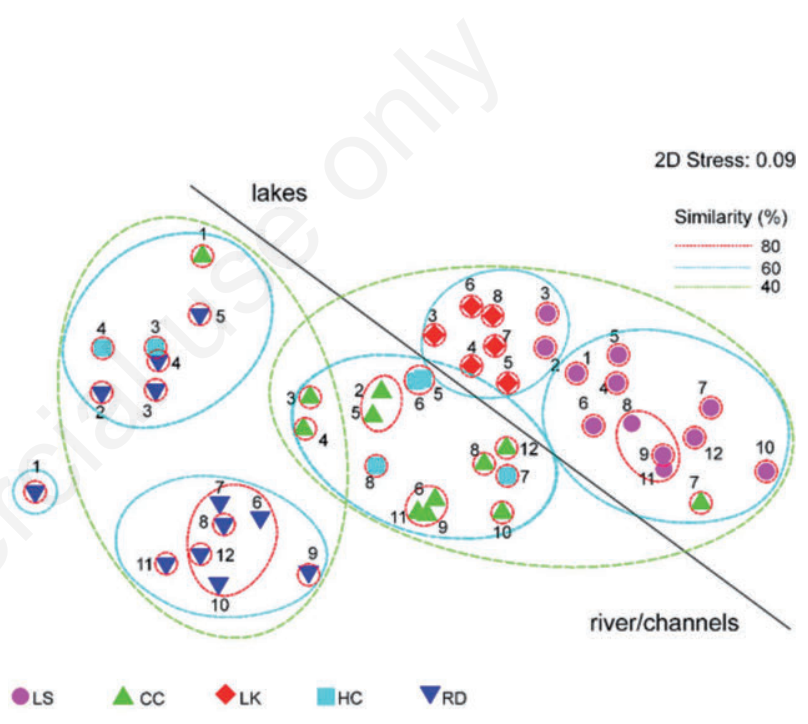

Fig. 5. nMDS plot of the rotifer functional group assemblages (square root transformed data) with similarity groups showing differences among the studied sites. Cluster analysis of rotifer resemblance is presented as an nMS overlay.

Tab. 1. Rotifer functional feeding guilds among the studied sites in 2008 with untransformed mean values (ind $\mathrm{L}^{-1}$ ). Ratio of microfilterfeeders and macrofilter-feeders was calculated on mean abundance data.

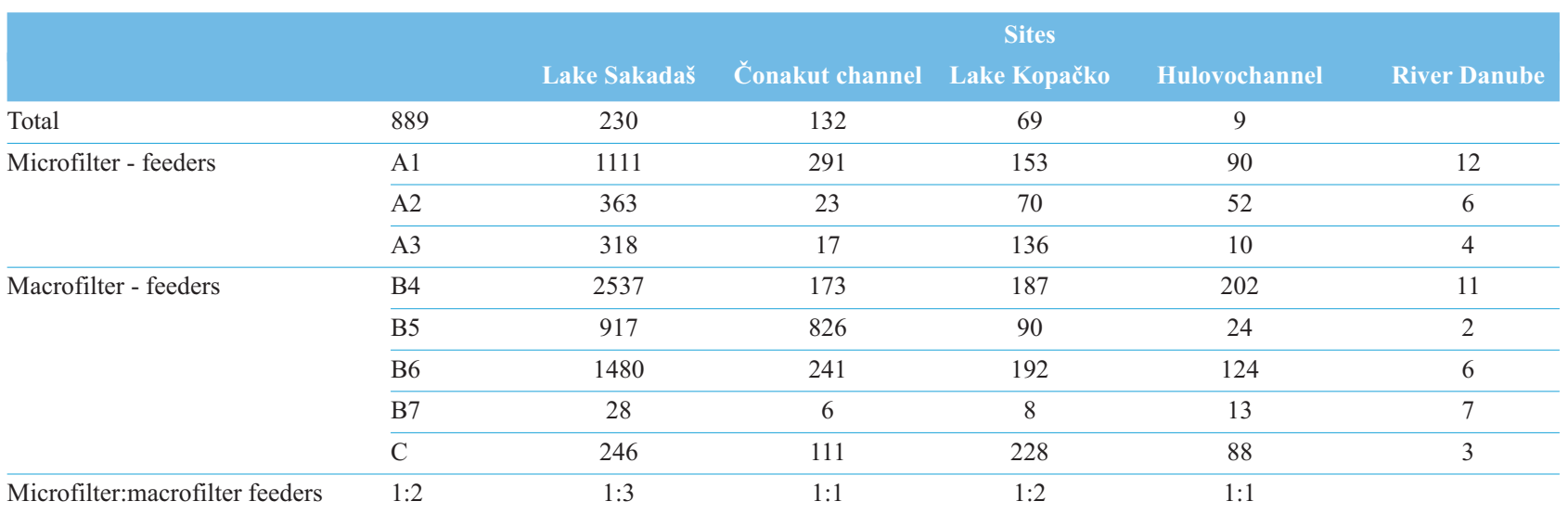


related to its position in the studied floodplain and spatial autocorrelation, where proximity to the lakes could have influenced dispersal of zooplankton and increased the abundance of microcrustaceans. Lower dissimilarity in feeding guilds among Čonakut channel and Lake Kopačko compared to Lake Sakadaš indicate that Lake Kopačko has a more significant influence on zooplankton input in this channel system. Absence of microcrustacean control in Hulovo channel may be due to a significant wash-out effect, since a reduction in zooplankton abundance can be expected at ecosystem outlets at the proximity to the main river (Czerniawski and Domagała, 2013), like Hulovo site in our study, that may cause increased mortality of adult microcrustaceans (Obertegger et al., 2007). Decreased biomass of crustaceans directly affects rotifer growth through reduced exploitative competition among these groups (Obertegger et al., 2007), and thus limnological parameters primarily affected rotifer representation in this channel system.

The results indicate that not only the waterbody type dictates the rotifer representation in a specific environment, but the position in the floodplain and the distance from the main riverbed also significantly affect rotifer functional feeding guild distribution. Increased distance from the main riverbed resulted in increased rotifer numbers, as was recorded for phytoplankton species in Kopački rit (Mihaljević et al., 2015). As expected, functional feeding guild distribution in River Danube differed in rotifer composition compared to other sites reflecting the highest dissimilarity in environmental conditions and food resources compared to floodplain areas. Numerous authors found similar results, with the evident difference in rotifer assemblage, especially between the river and inland floodplain areas (LansacTôha et al., 2009; Górski et al., 2013; Goździejewska et al., 2016). The vast difference in spatial distribution among rotifer functional feeding guilds in the studied river-floodplain system is related mainly to environmental conditions and the amount of available food in time and space together with biotic interactions among zooplankton groups. A similar result was found by Obertegger and Manca (2011), confirming that the use of rotifer functional groups can detect patterns in trophic level interrelationships and thus providing deeper insights into ecosystem functioning.

No significant relationship was found among small bacterivore rotifers and microcrustacean competitors; I hypothesised that this could be related to the fact that bacteria are considered a supplementary food for cladocerans (Porter, 1984), especially in systems with a high density of edible algae. Interestingly, no macrofilter-feeder group that feeds on larger

Tab. 2. Results of the SIMPER analysis based on functional feeding guild abundance indicating discriminating groups contributing to dissimilarities between the studied sites and the one-way ANOSIM based on the same data. Statistically significant results are in bold

\begin{tabular}{|c|c|c|c|c|c|}
\hline \multirow[b]{2}{*}{ Groups } & \multirow[b]{2}{*}{ Average dissimilarity (\%) } & \multirow{2}{*}{$\begin{array}{c}\text { SIMPER } \\
\text { Discriminating group }\end{array}$} & \multirow[b]{2}{*}{ Contribution (\%) } & \multicolumn{2}{|c|}{ One-way ANOSIM } \\
\hline & & & & R-value & P-value \\
\hline LS:CC & 62.36 & $\begin{array}{l}\text { A1 } \\
\text { B6 }\end{array}$ & $\begin{array}{l}15.39 \\
1239\end{array}$ & 0.36 & 0.001 \\
\hline \multirow{2}{*}{ LS:LK } & 56.14 & A1 & 13.38 & 0.30 & 0.01 \\
\hline & - & B6 & 12.03 & & \\
\hline \multirow[t]{2}{*}{ LS:HC } & 66.75 & A1 & 16.47 & 0.39 & 0.004 \\
\hline & & B6 & 15.30 & & \\
\hline \multirow[t]{2}{*}{ LS:RD } & 85.40 & A1 & 21.43 & 0.90 & 0.001 \\
\hline & & B6 & 20.56 & & \\
\hline \multirow[t]{2}{*}{ CC:LK } & 46.90 & A1 & 10.85 & 0.003 & 0.43 \\
\hline & & B4 & 7.30 & & \\
\hline \multirow[t]{2}{*}{$\mathrm{CC}: \mathrm{HC}$} & 50.34 & $\mathrm{~A} 1$ & 12.52 & 0.10 & 0.18 \\
\hline & & B6 & 8.99 & & \\
\hline \multirow[t]{2}{*}{ CC:RD } & 68.20 & B6 & 15.99 & 0.52 & 0.001 \\
\hline & & A1 & 15.07 & & \\
\hline \multirow[t]{2}{*}{$\mathrm{LK}: \mathrm{HC}$} & 61.86 & $\mathrm{~A} 1$ & 15.55 & 0.34 & 0.006 \\
\hline & & $\mathrm{C}$ & 9.95 & & \\
\hline \multirow[t]{2}{*}{ LK:RD } & 69.53 & A1 & 17.85 & 0.56 & 0.001 \\
\hline & & B6 & 13.73 & & \\
\hline \multirow[t]{2}{*}{ HC:RD } & 49.34 & $\mathrm{~A} 1$ & 12.08 & -0.002 & 0.50 \\
\hline & & B6 & 7.34 & & \\
\hline
\end{tabular}

LS, Lake Sakadaš; CC, Čonakut Channel; LK, Lake Kopačko; HC, Hulovo Channel; RD, River Danube. One-way ANOSIM global test: R-value 0.41, P-value 0.001. 
phytoplankton showed any correlation with Daphnia. A lack of relation between herbivorous rotifers and microcrustacean competitors can be a consequence of the data analyses where periods with and without cyanobacterial blooms were jointly considered. Usually, during periods of increased cyanobacterial abundance, microcrustaceans cannot control large algae biomass (Krevš et al., 2010), which enables smaller plankton to dominate (Jiang et al., 2014). In these conditions, the nutrient cycling goes through rotifers (Krevš et al.,

Tab. 3. Multiple linear regression analysis of the rotifer functional feeding guild relationship with biotic variables performed on the investigated sites in 2008. Statistically significant results are in bold.

\begin{tabular}{|c|c|c|c|c|}
\hline Dependent variable & Independent variables & Standardised $\beta$ coefficient & $\mathrm{t}$ & P-value \\
\hline \multirow[t]{5}{*}{ A1 } & Daphnia & 0.02 & 0.13 & 0.90 \\
\hline & Small cladocera & -0.23 & -1.24 & 0.22 \\
\hline & Juvenile copepoda & 0.35 & 1.84 & 0.07 \\
\hline & Adult copepoda & 0.01 & 0.07 & 0.94 \\
\hline & & $\mathrm{R}^{2}=0.10 ; \mathrm{F}(4.43)=1.14$ & n & \\
\hline \multirow[t]{5}{*}{$\mathrm{A} 2$} & Daphnia & -0.06 & -0.37 & 0.71 \\
\hline & Small cladocera & -0.10 & -0.53 & 0.60 \\
\hline & Juvenile copepoda & 0.19 & 0.97 & 0.34 \\
\hline & Adult copepoda & 0.02 & 0.09 & 0.92 \\
\hline & & $\mathrm{R}^{2}=0.03 ; \mathrm{F}(4.43)=0.31$ & & \\
\hline \multirow[t]{5}{*}{$\mathrm{A} 3$} & Daphnia & 0.08 & 0.56 & 0.58 \\
\hline & Small cladocera & -0.21 & -1.17 & 0.25 \\
\hline & Juvenile copepoda & -0.18 & -1.01 & 0.32 \\
\hline & Adult copepoda & 0.51 & 2.83 & 0.01 \\
\hline & & $\mathrm{R}^{2}=0.16 ; \mathrm{F}(4.43)=2.01$ & & \\
\hline \multirow[t]{5}{*}{ B4 } & Daphnia & -0.19 & -1.40 & 0.17 \\
\hline & Small cladocera & -0.28 & -1.77 & 0.08 \\
\hline & Juvenile copepoda & 0.71 & 4.27 & 0.00 \\
\hline & Adult copepoda & -0.19 & -1.12 & 0.27 \\
\hline & & $\mathrm{R}^{2}=0.30 ; \mathrm{F}(4.43)=4.70$ & & \\
\hline \multirow[t]{5}{*}{ B5 } & Daphnia & -0.18 & -1.37 & 0.18 \\
\hline & Small cladocera & -0.28 & -1.76 & 0.08 \\
\hline & Juvenile copepoda & 0.70 & 4.25 & 0.00 \\
\hline & Adult copepoda & -0.19 & -1.15 & 0.26 \\
\hline & +2 & $\mathrm{R}^{2}=0.30 ; \mathrm{F}(4.43)=4.67$ & & \\
\hline \multirow[t]{5}{*}{ B6 } & Daphnia & 0.01 & 0.11 & 0.91 \\
\hline & Small cladocera & -0.11 & -0.74 & 0.46 \\
\hline & Juvenile copepoda & 0.58 & 3.78 & 0.00 \\
\hline & Adult copepoda & 0.17 & 1.10 & 0.28 \\
\hline & & $\mathrm{R}^{2}=0.40 ; \mathrm{F}(4.43)=7.22$ & & \\
\hline \multirow[t]{5}{*}{ B7 } & Daphnia & -0.01 & -0.09 & 0.93 \\
\hline & Small cladocera & 0.11 & 0.57 & 0.57 \\
\hline & Juvenile copepoda & -0.04 & -0.18 & 0.86 \\
\hline & Adult copepoda & -0.07 & -0.37 & 0.72 \\
\hline & & $\mathrm{R}^{2}=0.01 ; \mathrm{F}(4.43)=0.09$ & & \\
\hline \multirow[t]{4}{*}{$\mathrm{C}$} & Daphnia & -0.03 & -0.20 & 0.84 \\
\hline & Small cladocera & -0.07 & -0.50 & 0.62 \\
\hline & Juvenile copepoda & -0.13 & -0.95 & 0.35 \\
\hline & Adult copepoda & 0.52 & 3.83 & 0.00 \\
\hline
\end{tabular}


2010), but the opposite relationship might be expected in the absence of cyanobacteria. Another explanation is the low number of adult competitors, as in floodplain areas, hydrology often suppresses the abundant growth of microcrustaceans, and rotifers usually dominate the system (Baranyi et al., 2002; Schöll and Kiss, 2008; Lansac-Tôha et al., 2009; Chaparro et al., 2011; Górski et al., 2013). However, results showed a significant relationship between juvenile copepods and several rotifer groups. I presume these interactions involve both competition and predation effects since copepodites (especially later stages) often prey on rotifers and act as opportunists that exploit available food for population increase (Brandl, 2005). The complete lack of B7 interference with microcrustaceans suggests an absence of exploitative competition between these groups, probably as a result of B7's specific food requirement (Pollingher, 1987).

The significant relation of predatory rotifers with adult copepods indicates high competition between species that expands the scale of the consumed resources (Quintana et al., 2015). Here, rotifer assemblage consisted of high numbers of loricate species or the ones with spines. Numerous Keratella sp. and Polyarthra sp. species that usually show high levels of the escape response in the presence of predators (Brandl, 2005) are found throughout the study. Microcrustacean predation on rotifers can have a significant effect on the rotifer's within-group relationships by reducing the pressure of predatory rotifers on other rotifer species (Williamson and Gilbert, 1980; Kumar and Rao, 2001). These interactions might also account for the differences in rotifer feeding guilds among different studied habitats. The results of this study clearly show the discriminating power of different environmental characteristics and biotic processes in reshaping rotifer functional diversity.

\section{CONCLUSIONS}

The increased distance from the main riverbed resulted in increased rotifer numbers and individual feeding guild abundance changed with the position of the community within the floodplain. Rotifer functional diversity diverged even among similar habitat types, and the proportion of microfilter-feeders and macrofilterfeeders differed substantially. A difference in spatial distribution among rotifer functional feeding guilds was mainly determined by the environmental conditions at the individual site and the biotic interactions with microcrustaceans. Future studies in rotifer functional feeding guild approaches in floodplains should focus on the hydrology of the area and the occurrence of cyanobacterial blooms that directly affect zooplankton's food.

\section{ACKNOWLEDGMENTS}

Many thanks to the project's lead researcher Prof. Jasna Vidaković for the support. Goran Palijan PhD, Filip Stević PhD, Dubravka Špoljarić Maronić PhD and Vanda Zahirović are acknowledged for practical assistance in the field and in the laboratory. Igor Stanković PhD kindly provided a map of the study area.

The project was supported by the Croatian Ministry of Science, Education and Sports, research project No. 285-0000000-2674.

\section{REFERENCES}

Amoros C, Bornette G, 2002. Connectivity and biocomplexity in waterbodies of riverine floodplains. Freshwater Biol. 47:761-776.

APHA, 1992. Standard methods for examination of water and wastewater. American Public Health Association, Washington DC: 1268 pp.

Baranyi C, Hein T, Holarek C, Keckeis S, Schiemer F, 2002. Zooplankton biomass and community structure in a Danube River floodplain. Freshwater Biol. 47:473-482.

Benedetti F, Gasparini S, Ayata S-D, 2016. Identifying copepod functional groups from species functional traits. J. Plankton Res. 38:159-166.

Bērziņš B, Pejler B, 1987. Rotifer occurrence in relation to $\mathrm{pH}$. Hydrobiologia 147:107-116.

Bērziņš B, Pejler B, 1989a. Rotifer occurrence and trophic degree. Hydrobiologia 182:171-180.

Bērziņš B, Pejler B, 1989b. Rotifer occurrence in relation to temperature. Hydrobiologia 175:223-231.

Bonacci O, Tadić Z, Moržan A, Radeljak I, 2002. [Park prirode Kopački rit, Plan upravljanja. Osijek: Sektorska studija Hidrologija i meteorologija].[Management Plan, in Croatian]. Elektroprojekt, Zagreb: 117 pp.

Bonecker CC, Aoyagui AS, Santos RM, 2009. The impact of impoundment on the rotifer communities in two tropical floodplain environments: interannual pulse variations. Braz. J. Biol. 69:529-537.

Brandl Z, 2005. Freshwater copepods and rotifers: predators and their prey. Hydrobiologia 546:475-489.

Brendelberger H, 1991. Filter mesh size of cladocerans predicts retention efficiency for bacteria. Limnol. Oceanogr. 36:884894.

Catlin AK, Collier KJ, Duggan IC, 2016. Zooplankton generation following inundation of floodplain soils: effects of vegetation type and riverine connectivity. Mar. Freshwater Res. 68:76-86.

Chaparro G, Marinone MC, Lombardo R, Schiaffino MR, Guimarães A, O'Farrell I, 2011. Zooplankton succesion during extraordinary drought-flood cycles: a case study in a South American floodplain lake. Limnologica 4:371-381.

Chen SY, Feng Z, Yi X, 2017. A general introduction to adjustment for multiple comparisons. J. Thorac. Dis. 9:1725-1729.

Clarke KR, Warwick RM, 2001. Change in marine communities: an approach to statistical analysis and interpretation. PrimerE Ltd., Plymouth: 172 pp. 
Czerniawsk R, Domagała J. 2013. Reduction of zooplankton communities in small lake outlets in relation to abiotic and biotic factors. Oceanol. Hydrobiol. St. 42:123-131.

Czerniawski R, Sługocki Ł, Kowalska-Góralska M, 2016. Diurnal changes of zooplankton community reduction rate at lake outlets and related environmental factors. PLoS One 11:e0158837.

Dembowska EA, Napiórkowski P, 2015. A case study of the planktonic communities in two hydrologically different oxbow lakes, Vistula River, Central Poland. J. Limnol. 74:346-357. Doi: 10.4081/jlimnol.2014.1057

Duggan IC, Green JD, Shiel RJ, 2002. Distribution of rotifer assemblages in North Island, New Zealand, lakes: relationships to environmental and historical factors. Freshwater Biol. 47:195-206.

Farias A, Jaksic F, 2006. Assessing the relative contribution of functional divergence and guild aggregation to overall functional structure of species assemblages. Ecol. Inform. 1:36-375.

Fradkin S, 1995. Effects of interference and exploitative competition from large-bodied cladocerans on rotifer community structure. Hydrobiologia 313-314:387-393.

Galir Balkić A, Ternjej I, Bogut I, 2018a. Impact of habitat heterogeneity on zooplankton assembly in a temperate riverfloodplain system. Environ. Monit. Assess. 190:143.

Galir Balkić A, Ternjej I, Špoljar M, 2018b. Hydrology driven changes in the rotifer trophic structure and implications for food web interactions. Ecohydrology 11:e1917. Doi: 10.1002/eco.1917

Gauzens B, Thébault E, Lacroix G, Legendre S, 2015. Trophic groups and modules: two levels of group detection in food webs. J. R. Soc. Interface 12:20141176.

Gilbert JJ, 1985. Competition between rotifers and Daphnia. Ecology 66:1943-1950.

Gilbert JJ, 1996. Effect of food availability on the response of planktonic rotifers to a toxic strain of the cyanobacterium Anabaena flos-aquae. Limnol. Oceanogr. 4 1:1565-1572.

Górski K, Collier KJ, Duggan IC, Taylor CM, Hamilton DP, 2013. Connectivity and complexity of floodplain habitats govern zooplankton dynamics in a large temperate river system. Freshwater Biol. 58:1458-1470.

Goździejewska A, Glińska-Lewczuk K, Obolewski K, Grzybowski M, Kujawa R, Lew S, Grabowska M, 2016. Effects of lateral connectivity on zooplankton community structure in floodplain lakes. Hydrobiologia 774:7.

Gutkowska A, Paturej E, Kowalska E, 2013. Rotifer trophic state indices as ecosystem indicators in brackish coastal waters. Oceanologia 55:887-899.

Hampton SE, 2005. Increased niche differentiation between two Conochilus species over 33 years of climate change and food web alteration. Limnol. Oceanogr. 50:421-426.

Hein T, Baranyi CGJ, Herndl JG, Wanek W, Schiemer F, 2003. Allochthonous and autochthonous particulate organic matter in floodplains of the River Danube: the importance of hydrological connectivity. Freshwater Biol. 48:220-232.

Jiang X, Yang W, Zhang L, Chen L, Niu Y, 2014. Predation and cyanobacteria jointly facilitate competitive dominance of small-bodied cladocerans. J. Plankton Res. 36:956-965.

Jiménez-Contreras J, Nandini S, Sarma SSS, 2018. Diversity of Rotifera (Monogononta) and egg ratio of selected taxa in the canals of Xochimilco (Mexico City). Wetlands 38:10331044.

Joint I, Henriksen P, Flaten GA, Bourne D, Thingstad TF, Riemann B, 2002. Competition for inorganic nutrients between phytoplankton and bacterioplankton in nutrient manipulated mesocosms. Aquat. Microb. Ecol. 29: 145-159.

Junk WJ, Bayley PB, Sparks ER, 1989. The flood-pulse concept in river-floodplain systems. Can. J. Fish. Aquat. Sci. 106:110-127.

Karabin A, 1985. Pelagic zooplankton (Rotatoria + Crustacea) variation in the process of lake eutrophication. II. Modifying effects of biotic agents. Pol. J. Ecol. 33:617-644.

Kim HW, Hwang SJ, Joo GJ, 2000. Zooplankton grazing on bacteria and phytoplankton in a regulated large river (Nakdong River, Korea). J. Plankton Res. 22:1559-1577.

Kirk KL, Gilbert JJ, 1990. Suspended clay and the population dynamics of planktonic rotifers and cladocerans. Ecology 71:1741-1755.

Krevš PA, Koreivienė J, Mažeikaitè S, 2010. Plankton food web structure during cyanobacteria bloom in the highly eutrophic Lake Gineitiškès. Ekologija 56:47-54.

Kumar R, Rao TR, 2001. Effect of the cyclopoid copepod Mesocyclops thermocyclopoides on the interactions between the predatory rotifer Asplanchna intermedia and its prey Brachionus calyciflorus and $B$ angularis. Hydrobiologia 453-454: 261.268.

Lansac-Tôha FA, Bonecker CC, Velho LFM, Simões NR, Dias JD, Alves GM, Takahashi EM, 2009. Biodiversity of zooplankton communities in the Upper Paraná River floodplain: interannual variation from long-term studies. Braz. J. Biol. 69:539-549.

Lokko K, Virro T, Kotta J, 2017. Seasonal variability in the structure and functional diversity of psammic rotifer communities: role of environmental parameters. Hydrobiologia 796:287-307.

Mihaljević M, Getz D, Tadić Z, Živanović B, Gucunski D, Topić J, Kalinović I, Mikuska J, 1999. [Kopački rit. Pregled istraživanja i bibliografija].[Book in Croatian]. Croatian Academy of Arts and Sciences, Zagreb: 188 pp.

Mihaljević M, Stević F, Špoljarić D, Žuna Pfeiffer T, 2015. Spatial pattern of phytoplankton based on the morphologybased functional approach along a river-floodplain gradient. River Res. Appl. 31:228-238.

Obertegger U, Flaim G, 2015. Community assembly of rotifers based on morphological traits. Hydrobiologia 753:31-45.

Obertegger U, Flaim G, 2018. Taxonomic and functional diversity of rotifers, what do they tell us about community assembly? Hydrobiologia 823:79-91. Doi: 10.1007/s10750018-3697-6

Obertegger U, Flaim G, Braioni MG, Sommaruga R, Corradini F, Borsato A, 2007. Water residence time as a driving force of zooplankton structure and succession. Aquat. Sci. 69:575583.

Obertegger U, Manca M, 2011. Response of rotifer functional groups to changing trophic state and crustacean community. J. Limnol. 70:231-238. Doi: 10.4081/jlimnol.2011.231

Obertegger U, Smith HA, Flaim G, Wallace RL, 2011. Using the guild ratio to characterize pelagic rotifer communities. Hydrobiologia 662:157-162.

Okogwu OI, 2010. Seasonal variations of species composition 
and abundance of zooplankton in Ehoma Lake, a floodplain lake in Nigeria. Rev. Biol. Trop. 58:171-182.

Ooms-Wilms AL, Postema G, Gulati R, 1995. Evaluation of bacterivory of Rotifera based on measurements of in situ ingestion of fluorescent particles, including some comparisons with Cladocera. J. Plankton Res. 17:10571077.

Paidere J, 2012. Influence of flooding frequency on zooplankton in the floodplains of the Daugava River (Latvia). Acta Zool. Lituana 19:306-313.

Palijan G, Galir Balkić A, 2018. Effect of depth on food-web interactions in a thermally stratified floodplain lake following inundation. River Res. Appl. 34:328-337.

Peršić V, Horvatić J, 2011. Spatial distribution of nutrient limitation in the Danube River floodplain in relation to hydrological connectivity. Wetlands 31:933-944.

Pollingher U, 1987. Ecology of dinoflagellates: Freshwater ecosystems, p. 502-559. In: F.J.R. Taylor (ed.), The biology of dinoflagellates. Blackwell Scientific Publ., Oxford.

Porter KG, 1984. Natural bacteria as food resources for zooplankton, p. 340-345. In: M. J. Klug and C.A. Reddy (eds.), Current perspectives in microbial ecology. American Society of Microbiology, Washington.

Quintana XD, Arim M, Badosa A, Blanco JM, Boix D, Brucet S, Compte J, Egozcue JJ, de Eyto E, Gaedke U, Gascón S, de Solá LG, Irvine K, Jeppesen E, Lauridsen TL, LópezFlores R, Mehner T, Romo S, Søndergaard M, 2014. Predation and competition effects on the size diversity of aquatic communities. Aquat. Sci. 77:45-57.

Reckendorfer W, Keckeis H, Winkler G, Schiemer F, 1999. Zooplankton abundance in the river Danube, Austria: the significance of inshore retention. Freshwater Biol. 41:583-591.

Romanovsky YE, Feniova IY, 1985. Competition among Cladocera: Effect of different levels of food supply. Oikos 44:243-252.

Rubin MA, Leff LG, 2007. Nutrients and other abiotic factors affecting bacterial communities in an Ohio River (USA). Microb. Ecol. 54:374-383.

Schöll KN, Kiss A, 2008. Spatial and temporal distribution patterns of zooplankton (Rotifera, Cladocera, Copepoda) in the water bodies of the floodplain Gemenc (Duna-Dráva National Park). Opusc. Zool. Budapest 39:65-76.

Schöll K, Kiss A, Dinka M, Berczik A, 2012. Flood-pulse effects on zooplankton assemblages in a river-floodplain system (Gemenc floodplain of the Danube, Hungary). Int. Rev. Hydrobiol. 97:41-54.

Sharma BK, Sharma S, 2005. Biodiversity of freshwater rotifers (Rotifera, Eurotatoria) from North-Eastern India. Zoosyst. Evol. 81:81-88.

Simberloff D, Dayan T, 1991. The guild concept and the structure of ecological communities. Annu. Rev. Ecol. Evol. Syst. 22:115-143.

Sládeček V, 1983. Rotifers as indicators of water quality. Hydrobiologia 100:169-201.

Smith HA, Ejsmont-Karabin J, Hess TM, Wallace RL, 2009. Paradox of planktonic rotifers: similar structure but unique trajectories in communities of the Great Masurian Lakes (Poland). Verh. Internat. Verein. Limnol. 30:951-956.

Soares MCS, Lürling M, Huszar VL, 2010. Responses of the rotifer Brachionus calyciflorus to two tropical toxic cyanobacteria (Cylindrospermopis raciborskii and
Microcystis aeruginosa) in pure and mixed diets with green algae. J. Plankton Res. 32:999-1008.

Strickland JDH, Parsons TR, 1968. A practical hand-book of seawater analysis. Bull. Fish. Res. Board Can. 167:1-310.

Špoljar M, Dražina T, Habdija I, Meseljević M, Grčić Z, 2011a. Contrasting zooplankton assemblages in two oxbow lakes with low transparencies and narrow Emergent macrophyte belts (Krapina River, Croatia). Int. Rev. Hydrobiol. 96:175-190.

Špoljar M, Dražina T, Šargač J, Kralj Borojević K, Žutinić P, 2012. Submerged macrophytes as a habitat for zooplankton development in two reservoirs of a flow-through system (Papuk Nature Park, Croatia). Ann. Limnol.-Int. J. Lim. 48:161-175.

Špoljar M, Lajtner J, Dražina T, Malekzadeh-Viayeh R, Radanović I, Zrinščak I, Fressl J, Matijašec D, 2017. Disentangling food webs interactions in the littoral of temperate shallow lakes. Nat. Croat. 26:145-166.

Špoljar M, Omljanović T, Lalić I, 2011b. Eutrophication impact on zooplankton community a shallow lake approach. The Holistic Approach to Environment 1:131-142.

Tadić D, Vidaček Ž, 1999. [Klimatske, hidrološke i pedološke značajke], p. 23-28. In: M. Mihaljević, D. Getz, Z. Tadić, B. Živanović, D. Gucunski, J. Topić, et al. (eds.), [Kopački rit - Pregled istraživanja i bibliografija]. [Book in Croatian]. Hrvatska akademija znanosti i umjetnosti, Zagreb.

Tadić Z, Bonacci O, Bognar A, Jović F, Radeljak I, 2002. [Park prirode Kopački rit, Plan upravljanja. Osijek: Sektorska studija Upravljanje vodama].[Management Plan, in Croatian]. Hidroing d.o.o., Osijek: 113 pp.

Thomaz SM, Bini LM, Bozelli RL, 2007. Floods increase similarity among aquatic habitats in river-floodplain systems. Hydrobiologia 579:1-13.

UNESCO, 1966. Determinations of photosynthetic pigments in seawater. Monographs on oceanographic methodology. Report of SCOR-UNESCO Working Group 17, Paris: 69 pp.

Van der Gucht K, Cottenie K, Muylaert K, Vloemans N, Cousin S, Declerck S, Jeppesen E, Conde-Porcuna JM, Schwenk K, Zwart G, Degans H, Vyverman W, De Meester L, 2008. The power of species sorting: local factors drive bacterial community composition over a wide range of spatial scales. P. Natl. Acad. Sci. USA 104:20404-20409.

Wantzen MK, Junk JW, Rothhaupt K, 2008. An extension of the floodpulse concept (FPC) for lakes. Hydrobiologia 613:151-170.

Weigelhofer G, Preiner S, Funk A, Bondar-Kunze E, Hein T, 2014. The hydrochemical response of small and shallow floodplain water bodies to temporary surface water connections with the main river. Freshwater Biol. 60:781-793.

Wen X, Zhai P, Feng R, Yang R, Xi Y, 2017. Comparative analysis of the spatiotemporal dynamics of rotifer community structure based on taxonomic indices and functional groups in two subtropical lakes. Sci. Rep. 7:578.

Williamson CE, Gilbert JJ, 1980. Variation among zooplankton predators: the potential of Asplanchna, Mesocyclops, and Cyclops to attack, capture, and eat various rotifer prey, p. 509517. In: W.C. Kerfoot (ed.), Evolution and ecology of zooplankton communities. University Press of New England, Hanover.

Zimmermann-Timm H, Holst H, Kausch H, 2007. Spatial dynamics of rotifers in a large lowland river, the Elbe, Germany: How important are the retentive shoreline habitats for plankton community? Hydrobiologia 593:49-58. 